\title{
QUALITATIVE ANALYSIS AND TERRITORIAL METHODS: HOW TO IMPROVE EDUCATIONAL AND RESEARCH TOOLS IN GEOGRAPHY
}

\author{
Sandra Ricart \\ Departament de Geografia, Universitat de Girona, Plaça Ferrater Mora 1, 17071 Girona, Spain \\ sandra.ricart@udg.edu
}

\begin{abstract}
Interest in obtaining a more accurate snapshot of the territory is increasingly relevant in most geographic studies. This proposal is based on the stakeholder analysis approach and the governance model approach to analysing any topic with a geographical profile or interest from an educational and methodological point of view. The selection of those approaches and the application of some related techniques have been used to generate a new tool for identifying and characterizing the key stakeholders in order to understand their behaviour and its influence or power on decision-making processes. This methodology can be used by educational members and geographers as a working basis to analyse an exchange sociallearning from confronted interests.
\end{abstract}

\section{Indexing terms/Keywords}

geography, governance model approach, stakeholder analysis approach, tools, irrigation, territorial management

\section{Academic Discipline And Sub-Disciplines}

Geography; Environmental Sciences; History; Education; Sociology; Cultural Studies

\section{SUBJECT CLASSIFICATION}

Library of Congress Classification: G (Geography, Anthropology, and Recreation, subclass: GE)

\section{TYPE (METHOD/APPROACH)}

Historical Inquiry; Qualitative analysis; semi-structured interview and digital questionnaire, stakeholder profile, territorial management

\section{Council for Innovative Research}

Peer Review Research Publishing System

Journal: International Journal of Research in Education methodology

Vol. 7, No.2

ijremeditor@gmail.com

$\underline{\text { www.ijrem.com }}$ 


\section{INTRODUCTION}

In the context of increasing competition between territories, ecosystems and demands, there is increasing emphasis on the need to organize the process of negotiation among the diversity of stakeholders through the integration of different points of view, the nature of the problem, and the promotion of mutual benefits [1]. As a result, developers and managers of complex issues are gradually becoming interested in methods and tools that are able to integrate the diversity of interpretations of topics that cause debates and/or conflicts in time and space [2]. In this context, the territory encompasses many of the elements that generate discussions about its future dynamic and management: from the sum of physical variables and social factors to the contrast of ideas and demands among potential stakeholders, the maintenance of uncertainties and risks require adaptive actions [3].

With the approval of the international community, recent decades have witnessed a growing desire to integrate social discourse in the decisions of general interest, and this has led to a rise in participation as a justifiably essential component for promoting good governance [4]. Public participation in the management of topics linked to the territory or its natural resources has always been controversial [5]. Just two examples can be found in, first, the need to justify public participation as a suitable mechanism for promoting agreements between disparate interests and, second, the difficulty of identifying and selecting stakeholders who represent antagonistic discourses. As a process by which society takes part in decisions affecting it in situations with diverse points of view, participation has been defined as an exchange forum organized to facilitate communication between government representatives, stakeholders, groups of interest and the whole of society. That is, it is a feasible framework for generating new ideas, theories, methods, techniques and a favorable context for the review, verification, adjustment and redesign of existing knowledge. The concept, however, can also be interpreted as an opportunity to influence various topics for the purpose of improving the promotion of territorial development and the sustainable management of natural resources [6].

Despite its widespread acceptance and versatility in adapting to different contexts and themes [7], the analysis of participation has led to multiple interpretations that differ, for example, on what is meant by society's involvement and the sum of stakeholders. Although much of the literature tends to mix both concepts interchangeably, there are those who consider society and the public (the set of individuals who are generally without structure and organization) to be clearly distinc from stakeholders (organized groups of people who share common interests and a decisional system) [8]. Participation is a complex system with multiple effects, interactions, meanings, levels of involvement, methods and solutions, all of which have to adapt to the context of the topic. Also, the avant-garde tradition of participating in public policy has shown that if the public (society) is actively involved in the management of any topic generating debate, the likelihood of conflict is significantly reduced. In this sense, the main policies at the European level, such as the Water Framework Directive and the Common Agricultural Policy, will tend increasingly to adapt and integrate the participation of civil society into the decision-making processes (though not always successfully) [9].

In this regard, several authors emphasize the advantages of participation: [10] highlights the integration of different interests and opinions; [11] recognized the improvement in the debate from the use of local knowledge and experience; [12] emphasize public acceptance of decisions processes to enhance the promotion of social learning. However, there are many risks to be recognized in the consultation process: from the frustration of potential stakeholders [13] to the identification of new conflicts [14], to the involvement of stakeholders that are not representative [15], and to the empowerment of an interested point of view [16]. There has also been criticism of the commitment to extrapolating of the most effective public participation without regard to its cultural, socio-political and historical context, as well as criticism about reducing participation to a simple mechanism for disseminating and grouping information through workshops [17]. Much of this criticism relates to the connection between participation and mobilization, both linked to: the cultural values associated with society's recognition of environmental issues; the ability to view issues that affect the territory and that otherwise would remain in the background; and the possibility of negotiation, which requires an analysis of variables that are not always objectivable. That which will bring together much of the public policy affecting the commons under territorialisation will be the territory, sum of resources, uses, discourses, and main field of activity in the geographical analysis [18]. In this sense, territorialisation will be characterized by bringing together different perspectives on similar phenomena, different interpretations of future caseloads and competing demands that are based on the binomial naturesociety relationship [19]. In general, the issues related to the management of territory and natural resources are linked to unstructured problems, i.e. they are hardly analyzable from standardized procedures and techniques. At the same time, these caseloads need to be recognized and accepted by the plurality of stakeholders and their discourses. Authors such as [20] are committed to structuring issues around the management of the territory through a process of combining the diversity of perceptions linked to stakeholders and the creation of an adaptive knowledge base to address the new challenges based on the legitimacy of the decisions.

This paper will analyse the potential role of qualitative analysis, based on the stakeholder analysis approach and the governance model approach, to study topics with a geographical profile and motivation. In particular, these approaches will be based on the promotion of social learning and used to generate a geographical model to identify the relevant stakeholders involved in a territorial system in order to understand their behaviour and their influence on or power over decision-making processes. Its application to a case study (the Segarra-Garrigues irrigation system, Spain) will be useful for putting in practice its benefits and limitations. We hope that this paper will form the basis for a discussion on the potential role of qualitative analysis and 'social-learning' in monitoring territorial policies and practices from a geographical point of view. 


\title{
QUALITATIVE ANALYSIS AS A TOOL FOR PROMOTING THE TERRITORIAL ANALYSIS IN GEOGRAPHY
}

\begin{abstract}
One of the pillars of the geographic discipline is to understand the interaction dynamics between natural and social phenomena in a given space and time [21]. Several issues affect the territory and they require a variety of interpretations and discourses for their effective management [22]. Thus, it is essential to, first, analyze how positioned and adapted each stakeholder is in the face of present and future challenges, as well as to identify favorable affinities and avoidable confrontations between competing points of view. Secondly, it is useful to compile the weaknesses and potential attitudes of each stakeholder involved in the decision-making process. Qualitative methods have the ability to make the invisible visible, and they can indirectly reduce the likelihood of a probable or existing confrontation. Qualitative analysis and its ability to structure the profile of each discourse allow us to identify the potentiality of an agreement. In other words, it is a key mechanism for addressing potential conflicts in the implementation of a major idea, policy and project. Here, the intensity and timing of the participation process and its analysis would be marked by two variables: 1) the presence of public discussion spaces and, 2) the ability to influence the decision system. Both variables contribute to a noticeable reduction in the conflict around a project, when positive spaces are provided for participation, the exchange of ideas, and the confrontation of discourses.
\end{abstract}

\section{The subject as protagonism: The stakeholder analysis approach}

Identification of each of the conflicting interests and their categorization are key aspects in understanding the dynamics of the debate and/or conflict, as well as in fostering their mitigation and resolution [23]. In this sense, the stakeholder analysis approach is the dominant approach to analyzing conflicting interests, as it facilitates the incorporation of values and different demands into the same subject in order to understand the whole from its parts [24]. The stakeholders include all those who can individually and/or collectively determine or be affected by political decisions and actions [25]. There are several ways to identify stakeholders. Some authors [26] identify them based on their legitimacy, urgency and proximity to the topic of analysis, while others [27] distinguish those who have a financial and/or production interest from those who are motivated by principles and/or values. The goal is twofold: on the one hand, to improve the efficiency of the decisions which determine multisectorial policies; on the other hand, to minimize the degree of involvement and the impact of decisions by those stakeholders with a negative predisposition to collaborate. The increasing popularity of this approach reflects the interest in analyzing stakeholder characteristics as a mechanism for influencing the decision-making process, especially in reference to those managing the commons, such as the territory [28]. Access to direct information from stakeholders is relevant for providing an accurate snapshot of the postulates defended by each profile. Here, face-to-face structured interviews and/or multiple choice questionnaires are indispensable. In a complementary manner, creating cognitive maps and word clouds can be useful for visualizing key concepts from each of the discourses provided by the stakeholders [29].

\section{The object as protagonist: The governance model approach}

Stakeholders are connected in various ways, and they have the ability to influence each others' discourses. The analysis of these connections and influence has facilitated the development of specific techniques and methods that are able to adapt to the spatial and/or social topic [30]. The decision about complex issues becomes, therefore, a process that requires mutual learning, which continuously improves the governance of the decision-making process [31]. The governance model approach is a method capable of responding to the implicit complexity involved in the management of competing and conflicting issues, as well as to the legitimacy of the decision-making process when it is based on social, economic, political, cultural and environmental demands [32]. This process is illustrated graphically by social structures represented by nodes (stakeholders) that are connected by ties (relationships) showing different degrees of affinity, controversy and potential temporary agreements. In short, this method proposes a relational framework based on the analysis of the links between the diversity of the stakeholders and their capacity to build the territorial network and improve its governance in the management of the commons [33]. Using matrices is one of the simpler and clearer techniques for identifying links between stakeholders. One example is a matrix determined by the support or rejection of a policy or project with consequences for the territory. Another example could be a two-way matrix that is used to analyse stakeholders and determine their location based on their interests and power. Another useful method for representing the profile of the stakeholders is social network analysis. This method provides both the individual performance of the involved stakeholders and their ability to weave affinities and/or rivalries from among the remaining discourses in conflict [34]. In short, the different categories of social networks reflect how collective decisions are influenced by certain stakeholders and how this influence is conditioned by time. According to [35], it is a method based on the analysis of electronic questionnaire responses and which allows determination of: 1) the degree and frequency of interaction between the diversity of stakeholders; 2) the degree of stakeholder confidence in establishing synergies; 3 ) the degree to which the respective discourses overlap; and 4) the ability to establish mutual recognition among them.

\section{TERRITORIAL ANALYSIS: FROM COMPLEXITY TO COMPLICITY}

The specialized literature on the management and governance of territorial topics is based on a hypothesis that proposes the following: if there are more social ties among the diversity of stakeholders, then they will be more likely to define a joint action based on mutual benefit. In consequence, it will be possible to limit the likelihood of conflicts and to define a multifunctional strategy for the territory [36]. In this respect, and from a qualitative point of view, much of the empirical work begun in the late 1990s -and which became specialized from the beginning of the twenty-first century- has shown that including the diversity of interests and promoting ties can increase the willingness to co-operate, thus leading to 
multifunctional and transversal benefits [37]. In parallel, the analysis of the links between the divers of interests in the management and governance of territorial variables (such as natural resources and rural development) basically depends on two factors. On the one hand, there are the structural characteristics of the network, that is: their impact on management and transfer of knowledge, the ability to share information, and the potential to define an agreement between competing demands [38]. On the other hand, relations of power and strategy are sketched out, that is: the process of negotiation at the internal level (between stakeholders who are part of the same discourse); at the external level (between the discourse defended by one stakeholder and other interests); the temporary and spatial links between divergent or convergent discourses; and the ability to promote agreements

\section{From social to territorial networks}

Most of the studies published until now conclude that management based on cooperation initiatives that embrace a wide range of interests, attitudes and opinions of those directly affected are more likely to succeed than those processes with less representation [39]. The aim is to reaffirm the idea that, despite the challenge of coping with the inherent complexity in natural resource management, institutional representatives should function in parallel with social demands [40]. Social networks are gaining progressively greater attention in their commitment to the adaptive management of natural resources based on diversity in the forms of participation and co-management [41]. Other authors [42] argue that stakeholders' social networks can develop and improve a society's ability to adapt to territorial challenges. This idea is shared by other authors who further emphasize the diversity of potential networks and the need to strike a parallel balance among the connections between confronted discourses and their legitimation by the whole of society [43].

Advances in the analysis of the links between nature and society has revealed the existence of social networks as a common denominator in the management of areas, topics and/or projects, all of which are situations that require stakeholders collaboration in order to face increasing challenges [44]. Based on this argument, we could talk of the territorial network as a graphic representation of (dis-)connections. These connections -or lack thereof- exist among the set of stakeholders who were previously selected for their ability to synthesize divers points of view that coexist in a territory. There are two primary characteristics in the network, social and territorial, and the difference between them is that the first focuses on analyzing the subject (the person, the society who defends and promotes an argument), while the second refers to the object (the discourse, social-learning and its spatial impact). Thus, the territorial profile of the network gives rise to two key questions: 1) Does a particular stakeholder's logic differ from that of the group? 2) Do the actions and discourses of a particular stakeholder have significant impact on decision-making processes that require effective territorial management? This distinction affects the behavior of each of the stakeholders and, in turn, it places the territory in a context where social demands are matched with technical, socio-economic, environmental and cultural issues in order to determine the future of the territory in a transversal and multifunctional way.

\section{Data sources, collection and codification}

Analyzing and interpreting the territory requires the use of information sources that are able to integrate quantitative and qualitative data. In this sense, we found it useful to apply two tools: the face-to-face structured interview and a multiple choice questionnaire. With these, it was possible to aggregate the objective aspects of the sensations, values, concerns and motivations that were reflected in each discourse. The results obtained from the face-to-face structured interview sought to understand the starting point of each stakeholder discourse regarding the topic. The multiple choice questionnaire sought, first, to impact the diverse perceptions about the topic and, second, to collect assessments regarding affinities and confrontations between stakeholders. The aim was to reflect three key aspects of managing complex subjects: 1) to meet one's own demands in the context of the needs of the whole; 2) to identify potential agreements between stakeholders and; 3 ) to define the basis of building a potential agreement that includes participation. Its transcription and analysis using qualitative analysis software Atlas.ti® 7 allowed highlighting concepts, perceptions and confronted points of view between the stakeholders [45]. The methodological process for emptying and analyzing these two techniques that we used to collect information is shown in Figures 1 and 2. 
1. TRANSCRIPTION OF THE INTERVIEW (Atlas.tiø 7) Emphasis on the discourse of each stakeholder: highlight the message

Identification of the variables which each discourse is based: keyideas

2. MICRO-ANALYSIS OF EACH STAKEHOLDER

Selection of key concepts for its comparison (Wordle ${ }^{\text {TM }}$ )

Characterization of each discourse from the coding process

3. COMPARISON BETWEEN KEY TOPICS OF EACH INTERVIEW (Excelø 14.0)

Analysis by concept, code (families), stakeholder (groups), and case studies

Identifying affinities and/or disputes linked to each case study

\section{GRAPHIC REPRESENTATION OF THE DISCOURSES}

Cognitive map of concepts and discourses identified for each stakeholder (Atlas.ti@ 7 and Wordle ${ }^{\mathrm{TM}}$ )

Matrices: interest vs power/ opposition vs support

Fig 1: Methodological process for the analysis of the face-to-face interviews
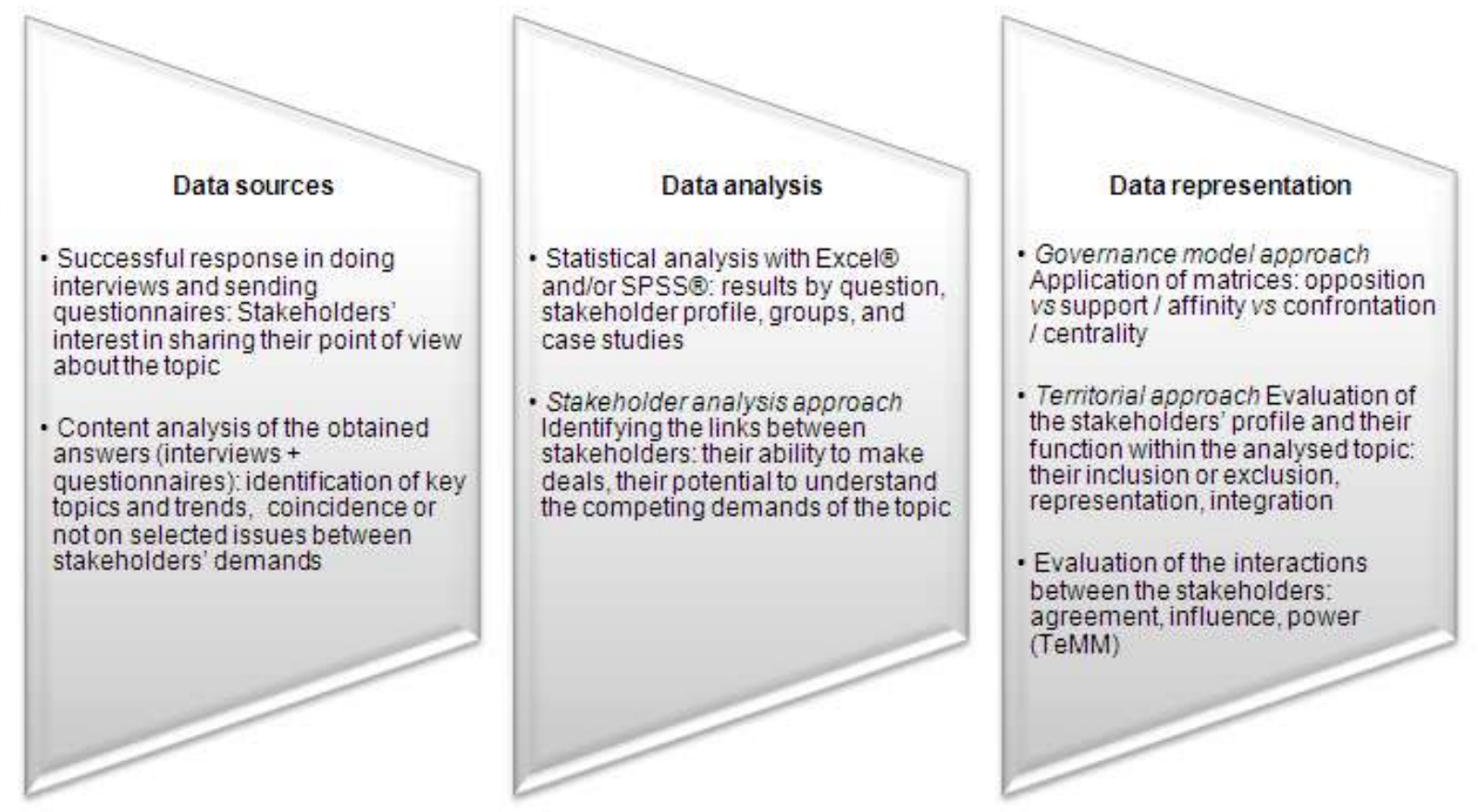

Fig 2: Methodological process for the analysis of the multiple choice questionnaires 
The first step in collecting useful information for the analytical process is to identify those snippets that provide some relevant information about the discourse of the stakeholder. This implies, therefore, a first reduction and/or simplification of the initial transcription of the face-to-face interview. This is done by delimiting in quotes significant parts of the transcribed text that will be useful in characterizing the profile of each stakeholder, as well as for subsequent comparisons with the other respondents. The next step is to encode this information in order to make an internal and/or external comparable analysis. Codification is a process in which a complex text is simplified in order to extract the meaning clearly. This process can be carried out by following two different yet compatible strategies: on the one hand, it is possible to use previous conceptual work and, therefore, work from a list of existing codes (top-down codification). On the other hand, it is possible to incorporate original data (transcribed interviews) for identifying potential concepts and, subsequently, convert them to codes (bottom-up codification).

\section{Modeling as a tool for territorial analysis}

In this context of competing interests, political strategies and power relations, the challenges and synergies between stakeholders have intensified. Consequently, the different discourses require methods that integrate territoriality as a key mechanism for reaching agreements in space and time (Figure 3). As a result, if stakeholders do not feel represented and/or involved in the analysis of alternatives to a complex problem, decision-making leans toward controversy and the resulting proposals can generate strong opposition that make agreements impossible [46]. Thus, the proposal for a model of social commitment seeks coexistence that has both a markedly sectoral vision and a tendency to socialize and integrate the demands of the territory. However, we must also keep in mind that, although predominantly stereotypical discourses aggravate a possible conflict, it is often true that the attitudes of different stakeholders are not static: they change over time between premises that have some variability, and their attitudes range widely between radicalism, flexibility and openness to negotiation. Thus, the factors that emphasize the importance of territory in decision-making can be summarized as: a need to integrate the management of interrelated variables, the involvement of stakeholders with conflicting goals, their coordination in defense of the general interest, and the opening of the debate to society.

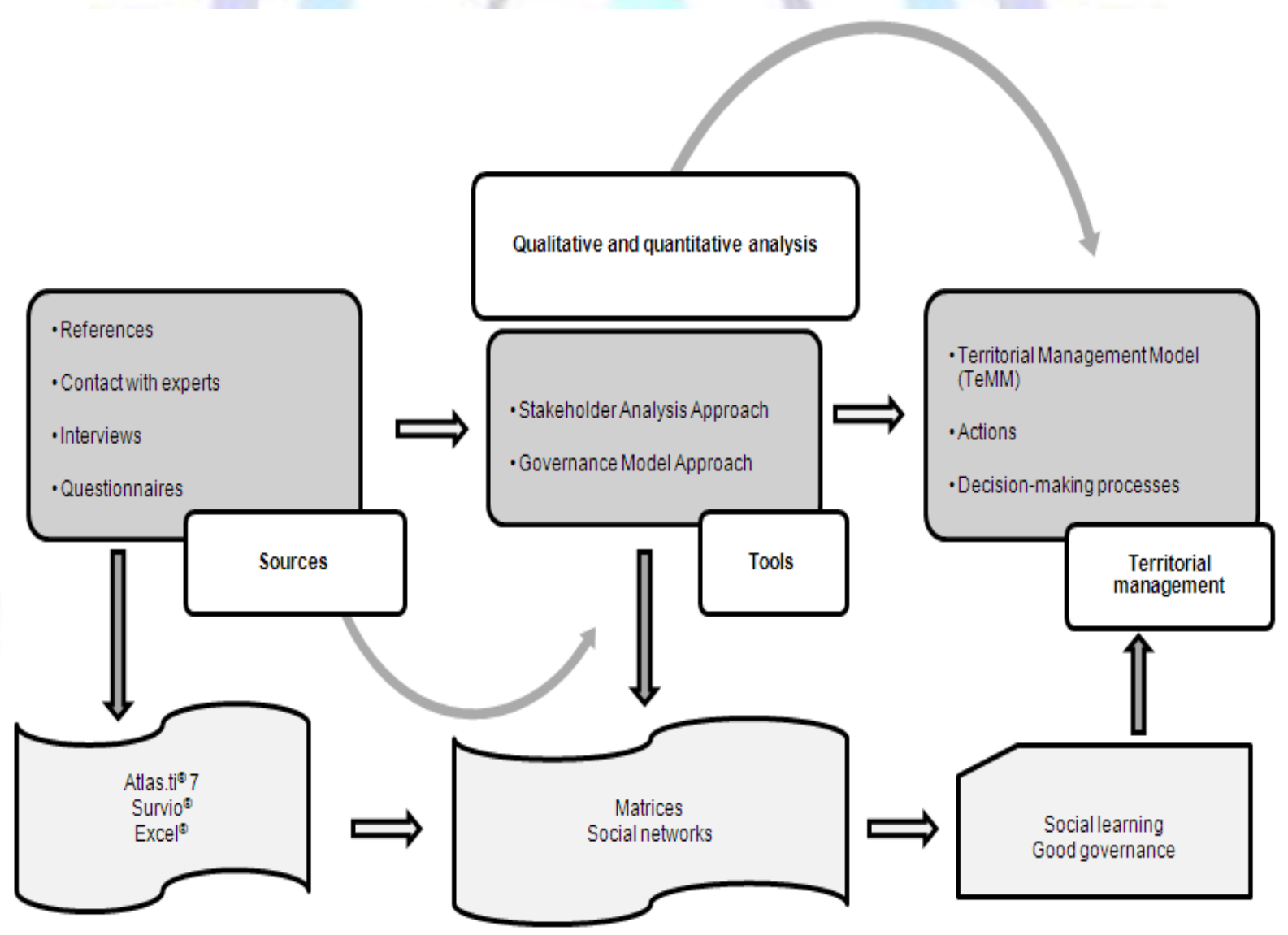

Figure 3. From a qualitative to a territorial approach

One way to represent the complexity of the territory is based on modelling [47]. Often their promotion has been used to respond to situations and/or dynamics that are complex to manage, where the legitimacy of the decision-making process is influenced by the diversity of points of view represented. Modelling is based on identifying potential confrontations and/or latent conflicts between different stakeholders, which will later be influenced in the mechanics of negotiation. In this respect, the use of participatory methodologies justified as a basis for integrative modelling due to its reflective, flexible and transferable character, which are in contrast to the rigidity of the methods applied in the practice of conventional 
science. As a conceptual framework for the representation of phenomena and trends, this practice has helped to promote links between nature and society. This modelling proposal aims first, to recognize the winners and losers in the range of interactions among conflicting interests and, second, to facilitate the transition from actions of dominance and resistance to cooperation [48]. In fact, other authors go a step further in stating that the links between stakeholders constitute a social network which can become more important than formal representative institutions [49].

The Territorial Management Model (TeMM) is based on the application of stakeholder analysis approach and the governance model approach, and it attemps to compile the location, relevance and strategy of each of the stakeholders involved in the management of a territorial topic, as well as the affinity and/or confrontation relationships that exist among the competing discourses (Figure 4). Given its diamond shape, the location of each discourse is not fortuitous: it reflects the desire to visually capture the distance between theoretically opposing discourses so that, in turn, the parties (non)willingness to establish synergies and/or agreements with other interests is represented. The distribution is justified by two factors. On the one hand, there is the combination of public-private relationships that dominate the development, implementation and management of a territorial topic. On the other hand, there is the confrontation between the two major discourses that reflect the debate on territorial dynamism. The model consists of a central diamond that includes in its vertices the diversity of discourses about the topic. The second-tier diamonds internally reproduces the set of interests, links and strategies of the different stakeholders involved in each context of the analysis. The sizes of the centre diamond and the sub-diamonds are a response to the (non-)existence of a dominant discourse. In each sub-diamond, the stakeholders are represented with nodes that are characterized according to three aspects: 1) the relevance and importance of the stakeholder (represented by the size of the node, i.e. the more prominence they have, the greater the size of the node); 2) the intensity of the stakeholder's action (nodes are represented by color, with darker colors indicating greater dominance of the activites); and 3) the relationship between stakeholders and discourses (represented by the position of the node, i.e. proximity between nodes indicating affinities between stakeholder actions). Also, the node at the juxtaposition between the central rhombus and the sub-rhombus is occupied by the stakeholder that represents the stakeholders' categories. Furthermore, the links between the different stakeholders are represented by arrows that can be unidirectional or bidirectional and permanent or temporary, depending on the nature of the relationship between stakeholders.

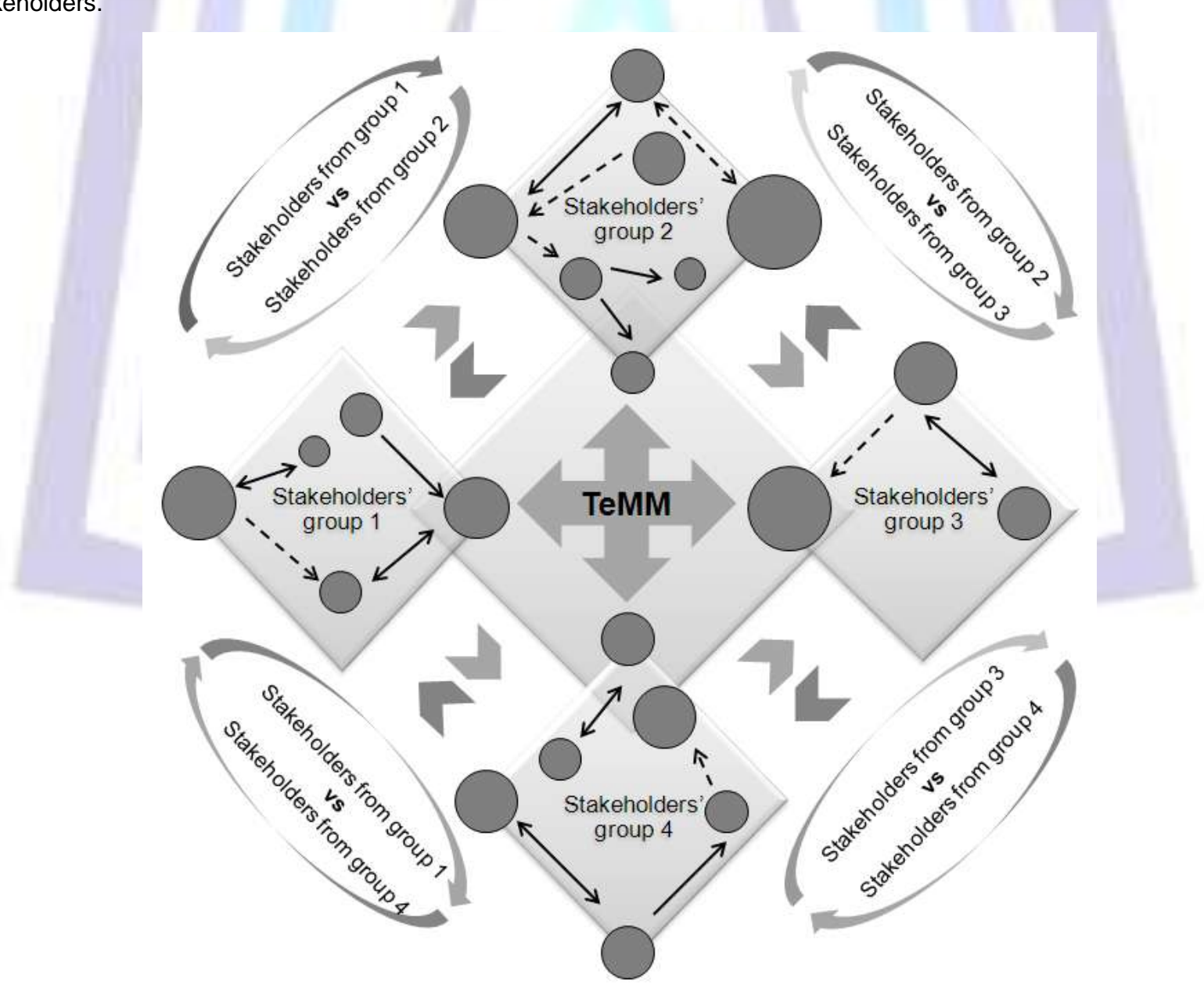

Figure 4. Theoretical representation of the TeMM 


\section{CONTRIBUTIONS FROM THE APPLICATION OF TeMM TO THE SEGARRA- GARRIGUES IRRIGATION SYSTEM}

Irrigation is one of the variables that generate concern in political, technical/expert and social ways, at different scales and in different contexts [50]. Consequently, four main challenges must be faced when managing water and land resources, the environment, rural development and irrigation [51]: 1) food production (dealing with the rising trend in global nutritional requirements as well as the guarantee of access to food); 2) environmental externalities (negative effects on soil productivity and harm to ecosystems and the common good); 3) institutional priorities (the diversity of interests and the rise of social participation require an effort to integrate sectoral synergies in a bottom-up approach); and 4) social demands (the amount of synergies in terms of rural development, landscape and cultural heritage requires a holistic and integrated perspective). In this sense, irrigation management is associated with a complex form of management that can hardly focus on a single variable, method or technique.

\section{The Segarra-Garrigues irrigation system}

The Segarra-Garrigues system covers about 105,000 hectares $(70,150$ ha potentially irrigated) spread across a total of 73 municipalities in six counties of Lleida (North-eastern Spain). The irrigation canal extends about $85 \mathrm{~km}$ from the Rialb dam to the newly built reservoir of L'Albagés (Figure 5). The coincidence in space and time of the irrigation project and the delimitation of the SPAs (which suppose a reduction in the potential irrigation area) have created a conflict between two key positions: those who defend rainfed productivity along with maintaining the boundary of a protected steppe area; and those who defend the irrigation system as the last chance to ensure the survival of agricultural production in the area. These two major discursive positions have resulted in debates on topics like the industrialization of agriculture, the concern for a lack of generational change, the management of water resources at the watershed level, the recognition of environmental services, the impacts of agriculture, and the role of citizen participation. As a result, its development, management and the competing water uses have led to different interpretations about the irrigation project and where the priorities should lie: food security vs. environmental value; energy production vs. recreational activities; rural development vs. land multifunctionality.

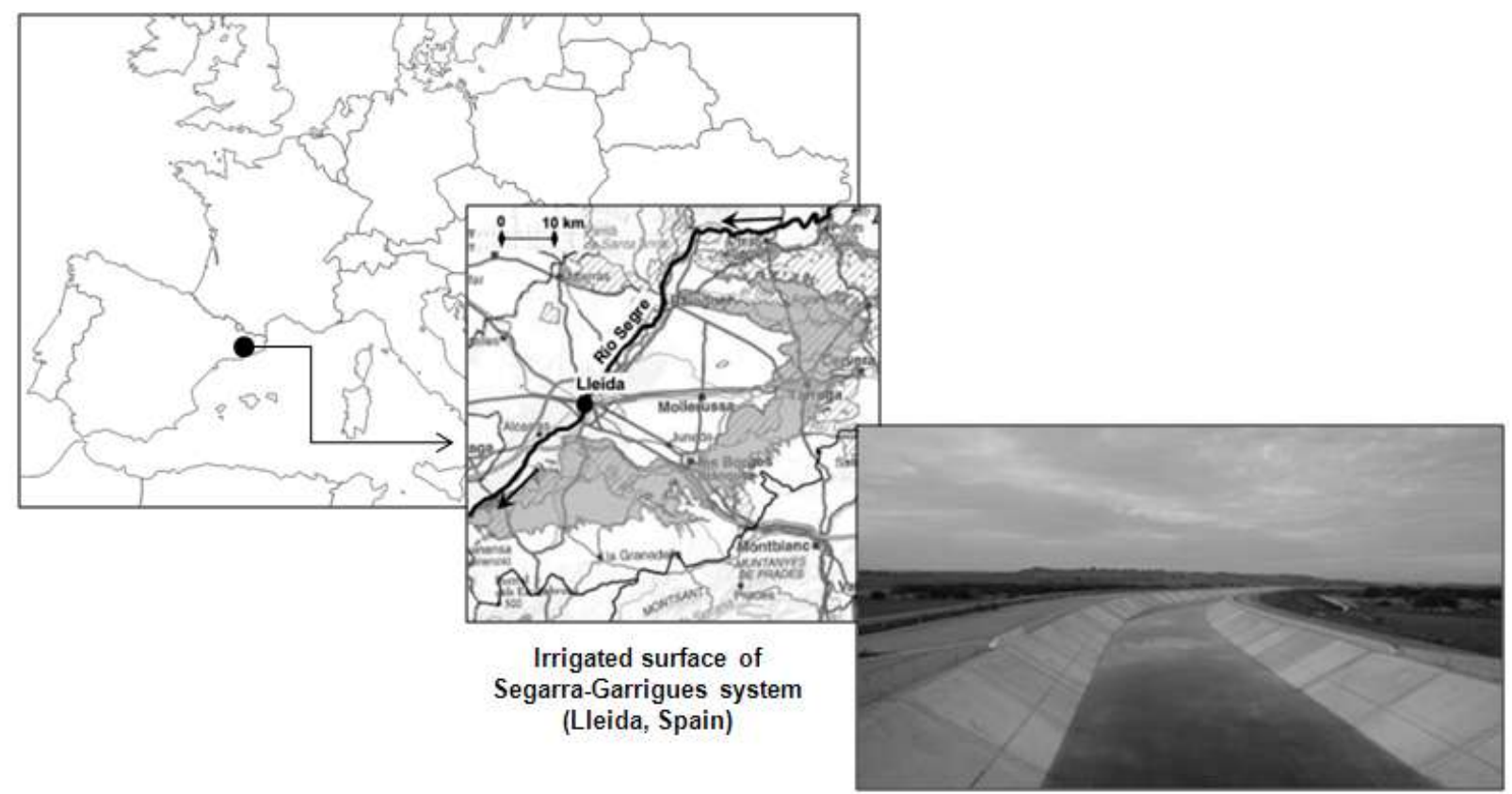

Figure 5. Location of the Segarra-Garrigues irrigation system

\section{Methodology}

A total of 17 stakeholders from its representativeness were identified and organized according to 4 interest groups: (1) public services (public administration); (2) private services (land and water consortiums, hydropower companies; (3) the rural community (syndicates and professional organizations); and (4) civil society (environmental, social and territoria platforms) (Table 1). The face-to-face structured interviews were conducted in November 2012. The results were analysed using the software Atlas.ti ${ }^{\Theta} 7$ and by creating a codification system based on 30 codes and 4 family codes (WATER, IRRIGATION, AGRICENV and GOVERNANCE) (Table 2). In addition, each stakeholder received a digital questionnaire by Survio ${ }^{\circledR}$ Platform. In this regard, the questionnaire was designed as a complement to the interview, and it was organized into three sections: (a) intrinsic characterization of the stakeholder and the valuation received from other stakeholders; (b) definition of potential (non-)links between conflicting positions and; (c) the ability to establish alliances to define an agreement that clears the way for and improves the irrigation project. Each of the 16 questions of the questionnaire provided new knowledge about the stakeholder and the stakeholders' group, which in turn facilitated the 
identification of common profiles among compatible and incompatible discourses [52]. A table of contents has been prepared for each of the codes created.

Table 1. Representative stakeholder list in the Segarra-Garrigues irrigation system

\begin{tabular}{|c|c|c|c|}
\hline Stakeholder & Acronym & Function & $\begin{array}{l}\text { Stakeholder' } \\
\text { group }\end{array}$ \\
\hline Confederación Hidrográfica del Ebro & $\mathrm{CHE}$ & $\begin{array}{l}\text { Ebro river Hydrographic Confederation } \\
\text { aims to rationalize agricultural water } \\
\text { use in harmony with the environment } \\
\text { in each new irrigation infrastructure }\end{array}$ & PUS \\
\hline Agència Catalana de l'Aigua & ACALL & $\begin{array}{l}\text { The Catalan Water Agency is the } \\
\text { public company responsible for } \\
\text { planning and managing the complete } \\
\text { water cycle in Catalonia, with similar } \\
\text { functions such as CHE but at regional } \\
\text { scale }\end{array}$ & PUS \\
\hline $\begin{array}{l}\text { Departament d'Agricultura, Ramaderia, Pesca, } \\
\text { Alimentació i Medi Natural (DAAM). Subdirecció } \\
\text { General d'Infraestructures Rurals }\end{array}$ & DAAMIR & $\begin{array}{l}\text { The rural administration in Catalonia is } \\
\text { responsible of the development of } \\
\text { policies and activities to promote } \\
\text { irrigation from sustainability values }\end{array}$ & PUS \\
\hline $\begin{array}{l}\text { Oficines comarcals del DAAM a la Noguera, el } \\
\text { Segrià i Les Garrigues }\end{array}$ & DAAMOC & $\begin{array}{l}\text { The regional offices of the rural } \\
\text { administration in Catalonia aims to } \\
\text { provide information and support to } \\
\text { potential irrigators }\end{array}$ & PUS \\
\hline Oficina del Regant (DAAM) & OFREG & $\begin{array}{l}\text { The irrigation office provide technical } \\
\text { support to irrigators in order to } \\
\text { maximize water use efficiency }\end{array}$ & PUS \\
\hline $\begin{array}{l}\text { Infraestructures de la Generalitat de Catalunya } \\
\text { S.A.U }\end{array}$ & INFRA & $\begin{array}{l}\text { The public company of Catalan } \\
\text { administration is responsible to plan, } \\
\text { build, preserve, maintain, modernize } \\
\text { and operate all kinds of infrastructure } \\
\text { and buildings from the Government } \\
\text { promotion and participation }\end{array}$ & PUS \\
\hline Aigües del Segarra Garrigues S.A & ASG & $\begin{array}{l}\text { Corporation from public and private } \\
\text { investment responsible to build the } \\
\text { Segarra-Garrigues infraestructure and } \\
\text { promote the involvement of potential } \\
\text { irrigators }\end{array}$ & PRIS \\
\hline Comunitat de Regants del Segarra-Garrigues & CRSEGA & $\begin{array}{l}\text { Community irrigation aims to promote } \\
\text { the development of irrigation practices } \\
\text { around the whole area of the Segarra- } \\
\text { Garrigues system }\end{array}$ & PRIS \\
\hline ENDESA & ENDESA & $\begin{array}{l}\text { Energy company is responsible for } \\
\text { pumping water to the highest levels of } \\
\text { the irrigated area }\end{array}$ & PRIS \\
\hline Unió de Pagesos de Catalunya & UP & $\begin{array}{l}\text { The main farm union defends the } \\
\text { necessity of the Segarra-Garrigues } \\
\text { irrigation canal to ensure the } \\
\text { productivity of agricultural sector }\end{array}$ & $\mathrm{RC}$ \\
\hline $\begin{array}{l}\text { Associació Agrària Joves Agricultors-Associació } \\
\text { d’Empresaris Agraris de Lleida }\end{array}$ & ASAJA/AEALL & $\begin{array}{l}\text { This farm union defends the necessity } \\
\text { of the Segarra-Garrigues irrigation } \\
\text { canal for promoting rural economy in } \\
\text { Lleida area }\end{array}$ & $\mathrm{RC}$ \\
\hline Joves Agricultors i Ramaders de Catalunya & JARC & $\begin{array}{l}\text { This farm union defends the necessity } \\
\text { of the Segarra-Garrigues irrigation } \\
\text { canal as the last chance for the } \\
\text { Catalan agriuclture }\end{array}$ & $\mathrm{RC}$ \\
\hline Institut Agrícola Català Sant Isidre & IACSI & This farm union defends the necessity & $\mathrm{RC}$ \\
\hline
\end{tabular}




\begin{tabular}{|c|c|c|c|}
\hline & & $\begin{array}{l}\text { of the Segarra-Garrigues irrigation } \\
\text { canal and accuses the environmental } \\
\text { associations for the delay in putting it } \\
\text { in place }\end{array}$ & \\
\hline Federació de Cooperatives Agràries Catalanes & FCAC & $\begin{array}{l}\text { The federation of agricultural } \\
\text { cooperatives considers that it has } \\
\text { been left out of the negotiation and } \\
\text { development process of the Segarra- } \\
\text { Garrigues irrigation canal }\end{array}$ & $\mathrm{RC}$ \\
\hline SEO/BirdLife & SEO/BL & $\begin{array}{l}\text { In collaboration with IPCENA, they are } \\
\text { the promoters of the EU complaint } \\
\text { about the lack of analysis of the } \\
\text { environmental impact of the Segarra- } \\
\text { Garrigues irrigation infrastructure }\end{array}$ & CS \\
\hline $\begin{array}{l}\text { Institució de Ponent per a la Conservació i } \\
\text { l'Estudi de l'Entorn Natural }\end{array}$ & IPCENA & $\begin{array}{l}\text { This environmental platform refuses } \\
\text { the need for the irrigation canal and } \\
\text { suggests the creation of a rainfed park } \\
\text { to promote the agricultural sector in } \\
\text { the Lleida plain }\end{array}$ & CS \\
\hline $\begin{array}{l}\text { Institució per a l'Estudi, Gestió i Recuperació } \\
\text { dels Ecosistemes Lleidatans }\end{array}$ & EGRELL & $\begin{array}{l}\text { This environmental association } \\
\text { promotes a more comprehensive } \\
\text { analysis of the Spetial Protected Areas } \\
\text { for promoting wild bird as an added } \\
\text { value for the agricultural sector }\end{array}$ & CS \\
\hline Lleida Ambiental & LLAMB & $\begin{array}{l}\text { This social platform reclaims good } \\
\text { ecological status for urban rivers (like } \\
\text { Segre, an effluent of Ebro river) for } \\
\text { promoting recreational use of water } \\
\text { and environmental systems }\end{array}$ & CS \\
\hline Compromís per Lleida & CxLL & $\begin{array}{l}\text { This territorial organization brings } \\
\text { together representatives from } \\
\text { administration, agricultural sector, } \\
\text { local enterprises, recreational and } \\
\text { environmental demands, and defends } \\
\text { the multi-functionality of the Segarra- } \\
\text { Garrigues irrigation canal }\end{array}$ & CS \\
\hline Plataforma en Defensa de l'Ebre & PDE & $\begin{array}{l}\text { This environmental platform defends } \\
\text { good ecological status for Ebro river } \\
\text { according to the promotion of } \\
\text { agricultural activity in a sustainability } \\
\text { way }\end{array}$ & CS \\
\hline
\end{tabular}

Legend: PUS (Public services), PRIS (Private services), RC (Rural community), and CS (Civil society)

Table 2. Example of one code description, named ACORD

\begin{tabular}{|l|l|}
\hline Code & ACORD \\
\hline Code family & GOVERNANCE \\
\hline Definition & $\begin{array}{l}\text { Valuation of the (non-)necessity and (non-)achievement of agreement/s in order to } \\
\text { improve the decision-making process. }\end{array}$ \\
\hline Description & $\begin{array}{l}\text { Discourses based on (non-)promotion of an agreement between competing } \\
\text { demands to benefit the management of complexity. Includes variables related to the } \\
\text { process of reaching an agreement, the factors that determine it and the } \\
\text { stakeholders willing to carry it out. }\end{array}$ \\
\hline When used & $\begin{array}{l}\text { Apply to the set of references that promote, justify and/or criticize the agreement as } \\
\text { a mechanism for improving governance. }\end{array}$ \\
\hline When not used & $\begin{array}{l}\text { Do not use it when there exists a direct link with participation (PARTICIP code), } \\
\text { conflicts between discourses (CONFLICT code) or examples of agreements } \\
\text { (EXEMGOV code). }\end{array}$ \\
\hline
\end{tabular}




\begin{tabular}{|l|l|}
\hline Example of quote & $\begin{array}{l}\text { "It is very difficult to reach an agreement but we understand that it is the only way to } \\
\text { benefit or damage anyone in the same way and intensity" }\end{array}$
\end{tabular}

\section{Results}

The analysis of the structured interviews has allowed us to collect a total of 411 quotes, of which civil society and the rural community contributed, respectively, 171 and 126 citations; public services 83; and private services 31 . The main topics expressed by the stakeholders representing public services are the social recognition of irrigation and the effects of irrigation in environmental flows. Private services agree on many of the references bounded by public services, especially regarding topics like the latent conflict between irrigators and environmentalists. The dominant discourse of the rural community focuses on the future agricultural model of the Lleida plain. Finally, civil society emphasizes the concern for water availability and its use by the agricultural sector; they also trivialize the environmental issues and criticize cereal monoculture. Before the codification process, we created a cognitive map with the keywords referenced by the stakeholders (Figure 6).

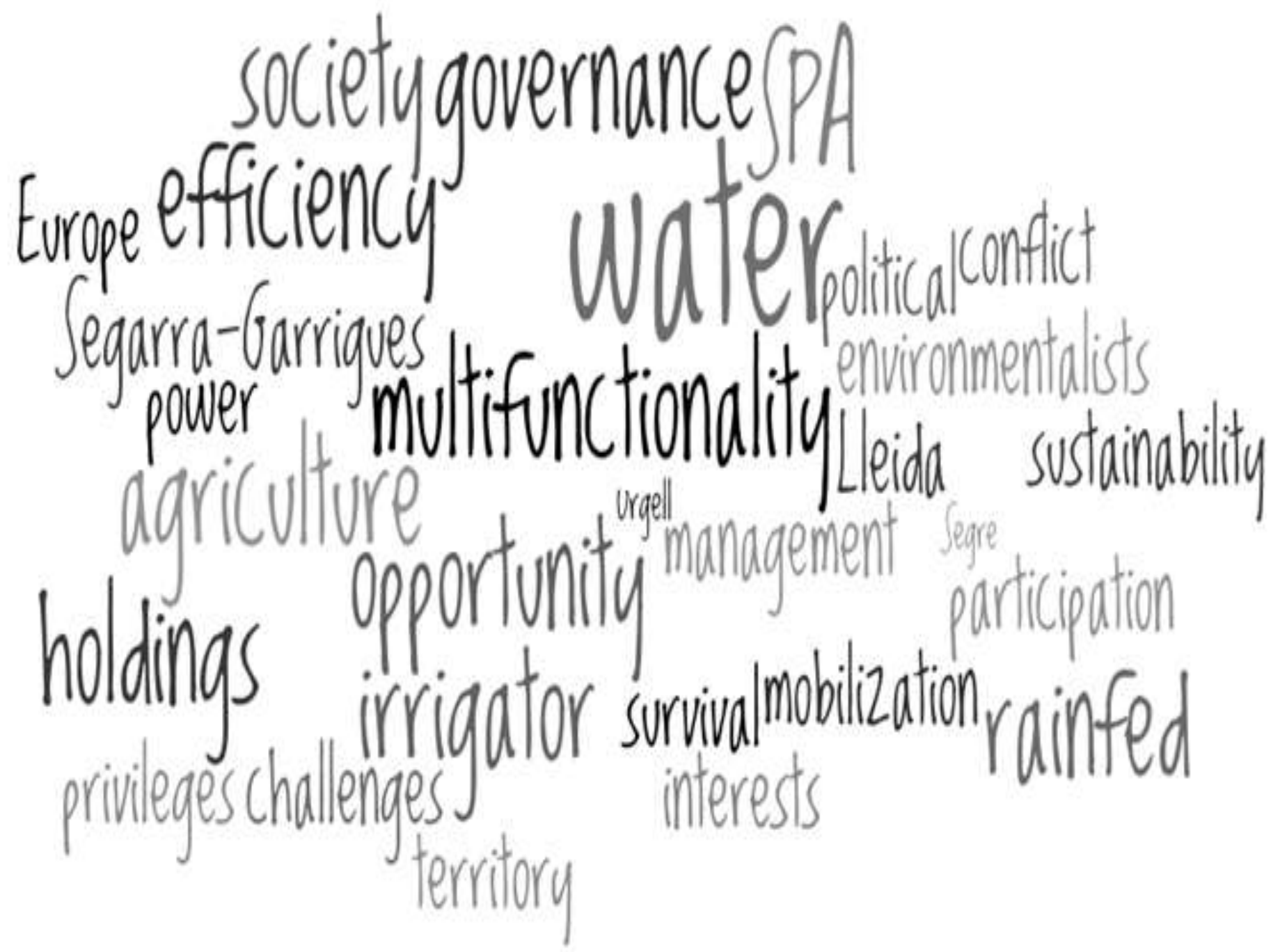

Figure 6. Cognitive map with the keywords provided by the stakeholders of the Segarra-Garrigues irrigation system In parallel, the analysis of codes with Atlas.ti ${ }^{\circledR} 7$ allowed us to graphically represent the codes used by each stakeholder. All this information has allowed us to define the territorial network of the Segarra-Garrigues irrigation system (Figure 7). 

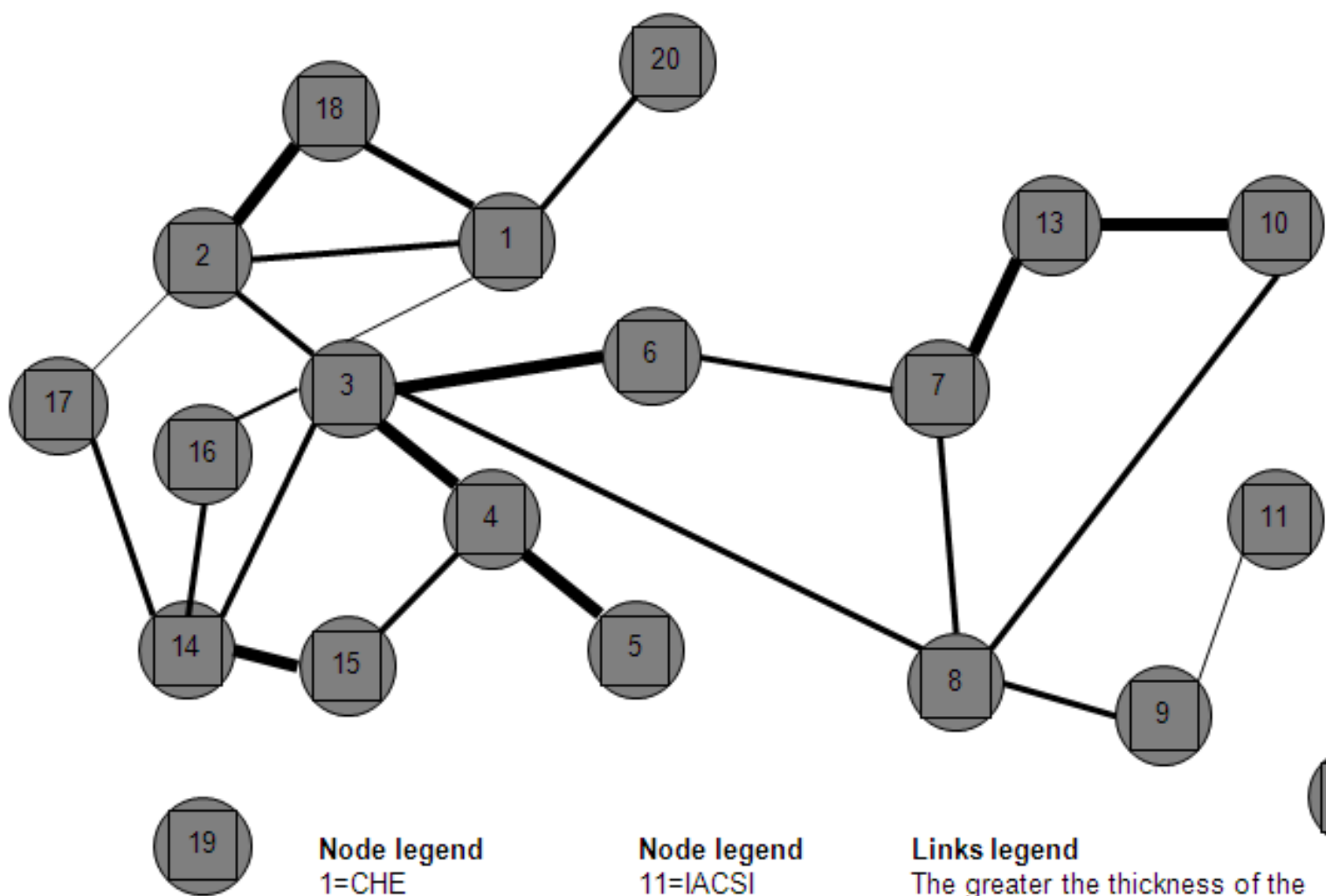

$\begin{aligned} & \text { Node legend } \\ & 1=\text { CHE }\end{aligned}$
$2=$ ACALL
$3=$ DAAMIR
$4=$ DAAMOC
$5=$ OFREG
$6=$ INFRA
$7=$ ASG
8=UP
$9=$ ASAJAVAEALL
$10=$ JARC

Node legend
$11=\mid$ IACSI
$12=$ FCAC
13=CRSEGA
14=SEO/BL
$15=$ IPCENA
$16=$ EGRELL
$17=$ LLAMB
$18=$ CXLL
$19=$ PDE
$20=$ ENDESA

Links legend

The greater the thickness of the bond, the greater is the intensity between the two stakeholders

\section{Number legend \\ 1-6: Public services \\ 7,13 and 20: Private services \\ 8-12: Rural community \\ 14-19: Civil society}

Figure 7. Territorial network based on the relationships between the stakeholders involved in the Segarra-Garrigues irrigation system

The analysis of the code families reveals how the quotations of WATER code family highlighted issues such as (a) concern for environmental flow, (b) the influence associated to water availability and control, and (c) the dominant agreement on the need to change the water management model. The quotes in the code family AGRICENV include aspects such as (d) (non-)recognition of farmers for their environmental function, (e) lobbying practices of irrigators and environmentalists, and (f) the role of society in defending the general interest of public investments. References to the IRRIGATION code family show topics like $(\mathrm{g})$ interest in the multifunctionality of the Segarra-Garrigues system, (h) the lack of an alternative project for the agriculture of Lleida plain, (i) the economic and environmental cost of water and energy efficiency, and (j) the recognition of the Special Protected Areas for their contribution to the landscape matrix. Finally, quotes referenced in the GOVERNANCE code family are based on topics such as (k) the difficulty of reaching agreements between competing water discourses, and (l) the need to involve the demands of those who live in and manage the territory.

Finally, it is considered necessary to promote irrigation management with a territorial character that is able to adapt to the complexity of the natural resources-society relationship. Thus, the Territorial Irrigation Management Model (TIMM) aims to compare the set of discourses related to irrigation from a cross-sectional point of view in space and time (Figure 8). In this sense, the desire to influence territorial irrigation management is part of a broader analysis framework for the territorial management of water. That is, the social organization of a territory according must be constructed in accordance with the associated water demands in parallel with the promotion of participatory and negotiated planning. 


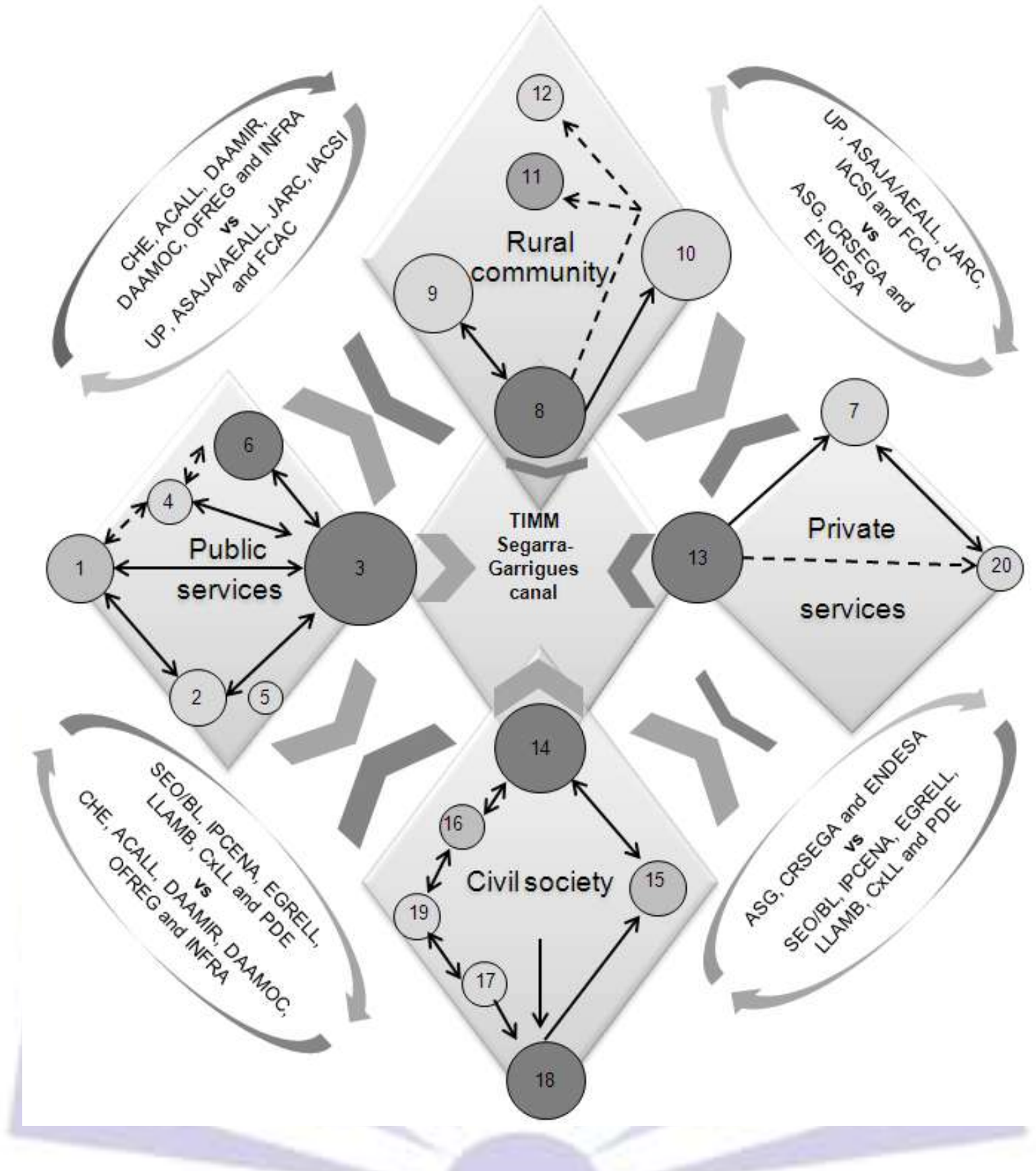

Figure 8. The TIMM applied to the Segarra-Garrigues irrigation system

\section{DISCUSSION AND CONCLUSIONS}

One of the pillars of the geographic discipline is to understand the dynamics of the interactions between natural and social phenomena in a given space and time. In this sense, issues related to the management of territory and natural resources are linked to unstructured problems that require multifunctional and transversal points of view, which the geographic discipline provides. Most of the studies published until now conclude that management based on co-operation initiatives are more likely to succeed if they include a wide range of interests, attitudes and the opinions of those (in-)directly affected; at least, they will succeed more so than those processes whit less representation. Based on the stakeholder analysis approach and the governance model approach, the proposed Territorial Management Model (TeMM) aims to facilitate the analysis of geographical topics from a mixed methodology (qualitative and quantitative). Its application in the Segarra-Garrigues irrigation system has revealed the significance of this model's ability to capture the existing discourses on complex issues, and its ability to define future strategies based on social learning and good governance. Some of the variables that this model potentially analyses are: mutual recognition despite conflicting postulates; the existence of participation and discussion spaces; and the promotion of knowledge from technocracy to sociocracy. In this sense, this model and its ability to integrate the variables linked to territorial management can be useful to comprehend complex issues that require adaptive tools, transversal actions and legitimate policies. In consequence, territorial management is 
proposed as a useful tool for providing new knowledge about the existing interactions between competing water demands, which in turn will allow us to incorporate this social learning into European policies that increasingly focus on the management of the commons.

\section{REFERENCES}

[1] Falkenmark, M. 2003. Freshwater as shared between society and ecosystems: from divided approaches to integrated challenges. Phil. Trans. R. Soc. B. 358, 2037-2049.

[2] Schmidt-Lainé, C., Pavé. A. 2002. Environnement: modélisation et modèles pour comprendre, agir ou décider dans un contexte interdisciplinaire. Nat. Sci. Soc. 10 (1), 5-25.

[3] Oberle, A. P. 2004. Understanding public land management through role-playing. J. Georg. 103 (5), $199-210$.

[4] Luyet, V., Schlaepfer, R., Parlange, M. B., Buttler, A. 2012. A framework to implement stakeholder participation in environmental projects. J. Environ. Manage. 111, 213-219.

[5] Pahl-Wostl, C., Kranz. N. 2010. Water governance in times of change. Environ. Scie. \& Pol. 13, 567-570.

[6] Abernethy, C. L. 2010. Governance of irrigation systems: Does history offer lessons for today?. Irrig. \& Drain 59, 31-39.

[7] Beierle, T., Konisky, D. 2001. What are we gaining from stakeholder involvement? Observations from Environmental Planing in the Great Lakes. Environ. Plann. C 19, 515-527.

[8] Kessler, B. L. 2004. Stakeholder participation: A synthesis of current literature. Maryland: National Oceanic and Atmospheric Administration.

[9] Flora, C.B. 2012. Sustainability unpacked: food, energy and water for resilient environments and societies. Contemp. Sociol. J. Rev. 41(5), 679-681.

[10] Griffin, C. B. 1999. Watershed councils: An emerging form of public participation in natural resource management. J. Am. Water. Resour. As. 35 (3), 505-518.

[11] Irvin, R. A., Stansbury. J. 2004. Citizen participation in decision making: Is it worth the effort?. Public, Admin. Rev. 64 (1), 55-65.

[12] Junker, B. et al. 2007. Objectives of public participation: Which actors should be involved in the decision making for river restorations. Water. Resour. Res 43 (10), W10438.

[13] Reed, M. S., Graves, A., Dandy, N., Posthumus, H., Hubacek, K., Morris, J., Prell, C., Quinn, C. H., Stringer, L. C. 2009. Who's in and why? A typology of stakeholder analysis methods for natural resource management. J. Environ. Manage 90, 1933-1949.

[14] Kangas, J., Store. R. 2003. Internet and teledemocracy in participatory planning of natural resources management. Landscape. Urban. Plan 62, 89-101.

[15] Korfmacher, K. S. 2001. The politics of participation in watershed modelling. Environ. Manage. 27 (2), $161-176$.

[16] Buttoud, G., Yunusova. I. 2002. A "mixed model" for the formulation of a multipurpose mountain forest policy; theory vs practice on the example of Kyrgyzstan. Forest. Pol. Econo 4 (2), 149-160.

[17] Stenseke, M. 2009. Local participation in cultural landscape maintenance: Lessons from Sweden. Land Use Policy 26, 214-223.

[18] Ruzza, C., Bozzini, E., Crivellari, P., Petrella, A. 2009. Europa e territorio: governance rurale, partecipazione, sostenibilità. Soveria Mannelli: Rubbettino Università.

[19] Hommes, S., Vinke-de-Kruijf, J., Otter, H. S., Bouma, G. 2009. Knowledge and perceptions in participatory policy processes: Lessons from the Delta-Region in the Netherlands. Water. Resour. Manag. 23, 1641-1663.

[20] Orr, P., Colvin, J., King, D. 2007. Involving stakeholders in integrated river basin planning in England and Wales. Water. Resour. Manag. 21, 331-349.

[21] Garmendia, E., Stagl. S. 2010. Public participation for sustainability and social learning: Concepts and lessons from three case studies in Europe. Ecol. Econ. 69, 1712-1722.

[22] Brewington, L., Engie, K., Walsh, S. J., Mena, C. F. 2013. Collaborative learning and global education: Humanenvironment interactions in the Galápagos Islands, Ecuador. J. Geogr. 112 (5), 179-192.

[23] Lienert, J. Schnetzer, F., Ingold, K. 2013. Stakeholder analysis combined with social network analysis provides finegrained insights into water infrastructure planning processes. J. Environ. Manage. 125, 134-148.

[24] Laplume, A. O., Sonpar, K., Litz, R. A. 2008. Stakeholder Theory: Reviewing a theory that moves us. J. Manage. 34 (6), 1152-1189.

[25] Freeman, R. E. 2010. Strategic management: A stakeholder approach. New York: Cambridge University Press. 


\section{ISSN 2278-7690}

[26] Mitchell, R. K. Agle, B. R., Wood, D. J. 1997. Toward a theory of stakeholder identification and salience: The principle of who and what really count. Acad. Manage. Rev. 22, 853-886.

[27] Selman, P. 2004. Community participation in the planning and management of cultural landscape. J. Environ. Plan. Manage. 47, 365-392.

[28] Bolleyer, N., Börzel. T. 2010. Non-hierarchical policy coordination in multilevel systems. Euro. Pol. Sci. Rev. 2 (2), 157-185.

[29] Tegarden, D. P., Sheetz, S. D. 2003. Group cognitive mapping: a methodology and system for capturing and evaluating managerial and organizational cognition. Omega. 31, 113-125.

[30] Weible, C. M. 2005. Beliefs and perceived influence in a natural resource conflict: An advocacy coalition approach to policy networks. Polit. Res. Quart 58 (3), 461-473.

[31] Pahl-Wostl, C., Craps, M., Dewulf, A., Mostert, E., Tabara, D., Taillieu, T. 2007. Social Learning and Water Resources Management. Ecol. \& Soc. 12 (2), 5.

[32] Wangel, J. 2011. Change by whom? Four ways of adding actors and governance in backcasting studies. Futures 43 , 880-889.

[33] Rijke, J., Brown, R., Zevenbergen, C., Ashley, R., Farrelly, M., Morison, P:, van Herk, S. 2012. Fit-for-purpose governance: A framework to make adaptive governance operational. Environ. Sci. \& Pol. 22, 73-84.

[34] Prell, C. Hubacek, K., Reed, M. 2009. Stakeholder analysis and social network analysis in natural resource management. Soc. Natur. Resour. 22, 501-518.

[35] Dougill, A. J. Fraser, A. D. G., Holden, J., Hubacek. K., Prell, C., Reed, M. S., Stagl, S., Stringer, L. C. 2006. Learning from doing participatory rural research: Lessons from the Peak District National Park. J. Agr. Econ. 57 (2), $259-275$.

[36] Janssen, M. A., Ostrom, E. 2006. Adoption of a new regulation for the governance of common-pool resources by a heterogeneous population. In Inequality, Cooperation and Environmental Sustainability, eds. J. M. Baland et al., 60-96. New Jersey: Princeton University Press.

[37] Hanaki, N., Peterhansl, A., Dodds, P. S., Watts, D. J. 2007. Cooperation in evolving social networks. Manage. Sci. 53, 1036-1050.

[38] Bodin, Ö., Crona, B. I. 2009. The role of social networks in natural resource governance: what relational patterns make a difference?. Global. Environ. Chang. 19, 366-374.

[39] Bidwell, R. D., Ryan, C. M. 2006. Collaborative partnership design: The implications of organizational affiliation for watershed partnerships. Soc. Natur Resour 19 (9), 827-843.

[40] Carlsson, L., Sandström, A. 2008. Network governance of the commons. Int. J. Com. 2(1), 33-54.

[41] Anderies, J. M., Janssen, M. A., Ostrom, E. 2004. A framework to analyze the robustness of social-ecological systems from an Institutional perspective. Ecol. \& Soc. 9 (1), 18.

[42] Tompkins, E. L., Adger, W. N. 2004. Does adaptive management of natural resources enhance resilience to climatic change?. Ecol. \& Soc. 9 (2), 10.

[43] Newman, L., Dale, A. 2005. Network structure, diversity, and proactive resilience building: A response to Tompkins and Adger. Ecol. \& Soc. 10 (1), 2.

[44] Olsson, P., Gunderson, L. H., Carpenter, S. R., Ryan, P., Lebel, L., Folke, C., Holling, C. S. 2006. Shooting the rapids: Navigating transitions to adaptive governance of social-ecological systems. Ecol. \& Soc. 11 (1), 18.

[45] Chaudhry, A. M., Barbier, E. B. 2013. Water and growth in an agricultural economy. Agr. Econ 44(2), 175-189.

[46] Giordano, R., Passarella, G., Uricchio, V. F., Vurro, M. 2007. Integrating conflict analysis and consensus reaching in a decision support system for water resource management. J. Environ. Manage. 84, 213-228.

[47] Prell, C., Klaus, H., Reed, M. S., Quinn, C. H., Jin, N., Holden, J. 2007. If you have a hammer everything looks like a nail: "traditional" versus participatory model building. Interdiscipl. Sci. Rev. 32 (3), 263-282

[48] Adger, W. N., Brown, K., Tompkins, E. L. 2006. The political economy of cross-scale networks in resource comanagement. Ecol. \& Soc. 10 (2), 9.

[49] Scholz, J. T., Wang, C. L. 2006. Cooptation or transformation? Local policy networks and federal regulatory enforcement. Am. J. Polit. Sci. 50, 81-97.

[50] Martins, G., Brito, A. G., Nogueira, R., Ureña, M., Fernández, D., Luque, F. J., Alcácer, C. 2013. Water resources management in southern Europe: Clues for a research and innovation based regional hypercluster. J. Environ. Manage. 119, 76-84. 
[51] Vignola, R., McDaniels, T., Scholz, R. W. 2013. Governance structures for ecosystem-based adaptation: Using policynetwork analysis to identify key organizations for bridging information across scales and policy areas. Enviro. Sci. Pol. $31,71-84$.

[52] MacQueen, K., McLellan, E., Kay, K., Milstein, B. 1998. Codebook development for team-based qualitative analysis. Cult. Anthropol. Meth 10 (2), 31-36.

\section{Author' biography with Photo}

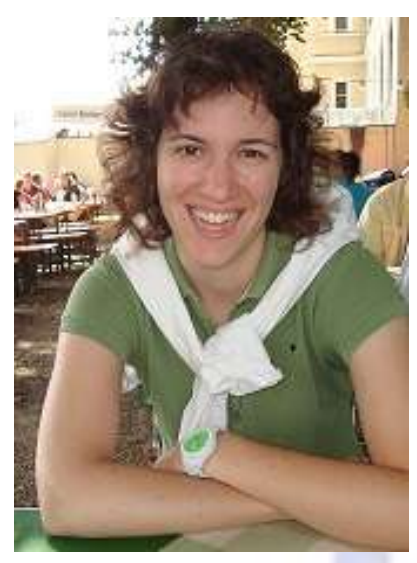

PhD on Experimental Sciences and Sustainability (Geography) by the Universitat de Girona (International mention, Excellent Cum Laude, 2014). MsC on Environment at the UdG (2008-2009). Degree in Geography at the UdG (2003-2008). Predoctoral Research Grant at Universitat de Girona, Geography Department, Environment and Geographic Information Technologies, 2009-2013. Mobility research grant to doctoral research stay in Laboratoire SET of ISRAM at Université de Pau et des Pays de l'Adour (UPPA) (2011). Mobility research grant to doctoral research stay at Dipartimento di Geografia e Scienza dell'Ambiente (DIGSUA) and at Dipartimento di Ingegneria Agraria di Milano (DIA), both linked to Universitá degli Studi di Milano (UNIMI) (2012).

I have been involved on national and European congresses and I am author of submitted publications into indexed journals like Journal of Geography and Earth Sciences, The Professional Geographer, Journal of Rural Studies, Revue Méditerranée, Sud-Ouest Européen, Documents d'Anàlisi Geogràfica, and Investigaciones Geográficas.

I am reviewer of seven international journals: Journal of Agriculture and Rural Development in the Tropics and Subtropics; Agriculture, Ecosystems and Environment; International Journal of Geosciences; Land Use Policy; Apuntes; Papeles de Geografía; International Journal of Research in Education Methodology.

I have been involved in the proposition of national research projects (REGDESERT, SABIOREG) and I am member of the international Consortium who has submitted the IRRIGEU project to WATER-2b-2015 call (H2020).

I collaborate with the iAgua project (www.iagua.es) as blogger and I have been involved in more than forty MOOCs (with Statement of Accomplishment) since 2011 from European and American universities by Coursera, Edx, Miriadax and SDSN platforms. I am member of the International Association for Hydro-Environment Engineering and Research (IAHR), Institute of the Environment (IMA-UdG) and Catalan Society of Geography (SCG). 